\title{
Using Information and Communication Technologies to Engage Students in the Later Years of Schooling in Learning Content and Literacy
}

\author{
Mohite Sunita Mahadeo, \\ Dept Of Science And Humanities Sahakar Maharshi Shankarrao Mohite Patil Institute Of Technology \& \\ Research, Shankarnagar-Akluj
}

\begin{abstract}
Literacy for a 21 st century context is far more complex than reading and writing print. As society and information and communication technology (ICT) has changed, so what counts as literacy and how a person is deemed to be literate has changed. Students from lowsocio-economic backgrounds in the later years of schooling require access to multiple literacies mediated through ICT and to teachers who are willing to provide opportunities for them to be taught explicitly. ICT can promote the learning of the content as well as learning the literacies associated with specific subject areas. This paper will focus on how three teachers in the later years of schooling (years 9-12) used technology to enhance learning and engagement of students in learning the literacies associated with their subject. They challenged the hegemony of print literacy by providing opportunities to develop students understanding, critique and creation of multimodal texts, but also supported students in achieving more effective print literacy. These teachers provided appropriate teaching for students from low socio-economicbackgrounds, engaging them in thinking, feeling and acting at high levels while simultaneously providing positive messages about their knowledge, ability, control, place and voice. Their pedagogical approach supported the development of cultural and social capital that will enhance their students' life options.
\end{abstract}

Keywords: Content literacy, Secondary education, Student engagement, Multiliteracies, Pedagogies.

\section{Introduction}

Literacy for a 21 st century context is more than the ability to read and write the printed word (UNESCO 2009; Gee 1990), it involves being able to use, critique and create texts using a range of media and modalities (New London Group 2000. It has become necessary for everyone to learn new forms of literacy and to develop the ability to locate, evaluate and effectively use information in a variety of ways (International Reading Association 2001; Leu et al. 2004). These new forms of literacy revolve around the literacy demands associated with technology, which is more than just digital literacy (Zammit 2008).

As society and information and communication technology (ICT) has changed, so what counts as being literate has changed (UNESCO 2009; National Council for the Teaching of English [NCTE] 2008). A literate person today 'possess(es) a wide range of abilities and competencies, many literacies...-from reading online newspapers to participating in virtual classrooms - [which] are multiple, dynamic, and malleable' (National Council for the Teaching of English [NCTE] 2008). They have to develop multiple literacies, which are largely mediated through ICT. But for some students from low socioeconomic (SES) backgrounds access to these multiple literacies can be limited as teachers focus on teaching the literacy associated with print because of the hegemonic place of print literacy in school to the detriment of students (Luke and Luke 2001). 'The real threat of a digital divide (will be)... that ... one group (will be) able to muster a wide range of semiotic tools and resources to persuade, argue, analyse, critique and interpret, and another group, lacking these semiotics skills, limited to pre-packaged choices' (Warschauer 2006). In addition, access to technology only will not increase the participation in society and life options of students from low SES backgrounds. Access to teachers who can mentor and support students' 21 st century learning through the use of ICT that will make the difference (Orlando 2013; Lawless and Pellegrino 2007). These teachers move 'beyond deficit notions of technology that dominate discussion of technology and poverty (the 'Digital Divide'), to the understanding that exciting and meaningful technology practice can take place' (Orlando 2013).

Haberman (2011) refers to exemplary teachers as 'star' teachers,' who 'lead students to become lifelong learners whose lives are guided by what they continue to learn' (Haberman 2011; Orlando 2013). Haberman (1991) proposes good teaching occurs whenever students:\&Are involved with issues they regard as vital concerns are involved with explanations of human differences are being helped to see major concepts, big ideas, and general principles and are not merely engaged in the pursuit of isolated facts are involved in planning what they will be doing are involved with applying ideals such as fairness, equity, or justice to their world are 
actively involved are directly involved in a real-life experience are actively involved in heterogeneous groups are asked to think about an idea in a way that questions common sense or a widely accepted assumption, that relates new ideas to ones learned previously, or that applies an idea to the problems of living \&Are involved in redoing, polishing, or perfecting their work \&Are involved with the technology of information access \& Are involved in reflecting on their own lives and how they have come to believe and feel as they do (Haberman 1991)

Teacher who engage students in learning provide students with a curric- ulum that engages them in thinking hard (high cognitive), feeling good (high affective) and active involvement (high operative) (The Fair Go Project 2006): small 'e'engagement. They employ a pedagogy that builds a student community of reflection, teacher inclusive conversations, student self-assessment and teacher feedback: the classroom processes. These classroom pro- cesses are employed to engage students in being active participants in their learning, whether it is focused on the literacies associated with different modes of representa- tion, content literacy or using ICT (Zammit and Callow 2013; Orlando 2013; Zammit 2011).

The Fair Go pedagogy also directly targets the five discourses of power (knowl- edge, ability, place, control and voice) through the selection of activities (curriculum), the classroom processes and assessment tasks (Munns et al. 2008; The Fair Go Project 2006). The message systems (Bernstein 1996) associated with the discourses of power either encourage or discourage students' engagement in learning. Teachers can disrupt the dis-engaging messages through changes to their curriculum, pedagogy and assessment to enhance engaging messages (Table 1) (Munns et al. 2013; The Fair Go Project 2006; Zammit 2011). Over time, students develop engagement with schooling and education, seeing them as a place for them and important to their future: big 'E' engagement.

\section{Methodology}

The 'Exemplary Teachers for a Fair Go' project involved 28 teachers teaching frompre-school to year 12, in Priority Schools Program (PSP) schools from city, regional and rural settings in NSW. The program supports government schools with the highest percentage of families from low SES to improve literacy, numeracy and engagement of students (NSW Department of Education and Communities 2008). It was a threeyear Australian Research Council funded project The three teachers covered in the case studies presented in this paper are drawn from the nine later years of schooling, years 9-12, case studies. At the time the data was gathered, year 9 and 10 were compulsory and year 11 and 12 were in the post- compulsory school years. A case study approach was employed because it providesin-depth study of an individual context 'in order to appreciate its uniqueness and complexity' (Basit 2010).

Case studies were written after a week of data gathering in the classroom, using an observation schedule based on the Fair Go pedagogical framework and motivational strategies employed from the MeE framework (Munns and Martin 2005). Detailed field notes were taken to confirm the narrative for the day's observation schedules. Each day a reductive process was employed by the two researchers and class teacher to summarise the day based upon the three observation schedules. These summaries were used to write up the final case study, which also included details of a highlight session of teaching chosen by the classroom teacher, and a summary of the teacher and students 'interviews. In addition, quotes from teachers and students obtained from the field notes were added to the summaries. To confirm the case study details, cross checking with the teachers was employed to ensure an accurate representation of their teaching from the data.

Discussion: Exemplary teachers, or what Haberman (2011) called 'star' teachers, provide access to multiple literacies mediated through ICT. The three teachers in this paper included learning that was intellectually challenging (high cognitive), interesting (high affective ) and required active involvement (high operative) (The Fair Go Project 2006), as they integrated ICT into the delivery and assessment of the curriculum. Their selection of content expanded students' access to different literacy practices associated with a range of multimodal texts with which they interact daily. In their curriculum decisions, about choice of ICT, content and 'literacy' in their lessons, they delivered engaging messages to students about their knowledge, ability, control, place and voice.

Technology was used as a tool for teaching and learning about the content as well as a means of creating texts: from notes to digital assessment items. While this was apparent in these three case studies, not all nine exemplary teachers used ICT in their teaching. However, when teachers did employ ICT it was seamlessly integrated and they accepted students could be more knowledgeable and have greater ability in the use of ICT than the teachers themselves. An understanding of design elements as well as linguistic knowledge present in multimodal electronic texts were necessary to transform information from a variety of sources using a range of modes into knowledge, assessed through creation of a text. Teachers who embed technology into the delivery of content and learning about text creation are more important than the actual provision of technology because they support students 21 st century literacies and learning and are equipping them for their future (Lawless and Pellegrino 2007) . 
While these teachers challenged the hegemony of print literacy, they still viewed students as needing to be taught how to create texts to demonstrate their understand- ing of the content. They explicitly taught students how to make their written texts better, so that they could put their point of view clearly and share their knowledge with others. Criteria for the texts that students created were provided as well as strategies to teach them about how to create a successful text, initiating them into the powerful texts in education, and supporting their social capital (Luke and Luke 2001; Patel Stevens 2011).

\section{Conclusion}

Teachers in the later years of schooling work with students who will soon be taking their first steps on their lifelong learning journey. Access to literacy practices that are authentic and relevant in today's society and workplaces is essential in order to provide students from low socioeconomic backgrounds with greater options in their life trajectories. The teachers actively planned to develop their students' 'repertoires of practice' through scaffolding and explicitly teaching multiple literacies mediated by ICT. The case studies of three secondary teachers from the Teachers for a Fair Go project demonstrate how teachers in the later years can provide students with challenging tasks, scaffolding students' engagement and learning of multiple liter- acies mediated through ICT.

\section{Acknowledgements}

The Teachers for a Fair Go Project was funded through an Australian Research Council Linkages grant (2008-2010). Thank you to the teachers who were part of that project and opened their classrooms and their teaching to us - especially Bronwen, Kate and Diane.

\section{References}

[1]. Basit, T. N. (2010). Conducting research in educational contexts. London: Continuum.

[2]. B ernstein, B. (1996). Pedagogy, symbolic control and identity: Theory, research, critique. London: Taylor \& Francis.

[3]. Gee, J. (1990). Social linguistics and literacies: Ideology in discourses. Londn: Falmer Press. Haberman, M. (1991). The pedagogy of poverty versus good teaching. Phi Delta Kappan, 73(4), 290-294.

[4]. Haberman, M. (2011). The beliefs and behaviours of Star Teachers. Teachers College Record International Reading Association (2001). Integrating literacy and technology into the curriculum: A position

[5]. statement of the International Reading Association http://www.reading.org/downloads/positions/ ps1048_technology.pdf: International Reading Association.

[6]. Lawless, K., \& Pellegrino, J. (2007). Professional development in integrating technology into teaching and learning: Knowns, unknowns, and ways to pursue better questions and answers. Review of Educational Research, 77(4), 575614. doi: $10.3102 / 0034654307309921$.

[7]. Leu, D., Kinzer, C., Coiro, J., \& Cammack, D. (2004). Toward a theory of new literacies emerging from the internet and other information and communication technologies. In R. Ruddell \& N. Unrau (Eds.), Theoretical models and processes of reading (5th ed., pp.1568-1611). Newark, DE: International Reading Association.

[8]. Luke, A. (2003). Literacy and the other: A sociological approach to literacy research and policy in multilingual societies. Reading Research Quarterly, 38(1), 122-128.

[9]. Luke, A., \& Luke, C. (2001). Adolescence lost/childhood regained: On early intervention and the emergence of the technosubject. Journal of Early Childhood Literacy, 1(1), 91-120.

[10]. Munns, G., \& Martin, A. (2005). It's all about MeE: A motivation and engagement frmaework. Sydney: Paper presented at the Annual conference of the Australian Association for Research in Education.

[11]. Munns, G., Sawyer, W., \& Cole, B. (Eds.). (2013). Exemplary teachers of students in poverty. London: Routledge.

[12]. Munns, G., Zammit, K., \& Woodward, H. (2008). Reflections from the Riot Zone: The Fair Go Project and Student Engagement in a Besieged.

[13]. Community. Journal of Children and Poverty, 14(2), 157-171.

[14]. National Council for the Teaching of English [NCTE] (2008). The NCTE definition of 21st century literacies.http://www.ncte.org/positions/statements/21stcentdefinition Accessed 20.11.112011.

[15]. New London Group (2000). A pedagogy of multiliteracies: Designing social futures. In B. Cope \& M. Kalantzis (Eds.), Multiliteracies: Literacy learning and the design social futures (pp.9-37). Mel- bourne: Macmillan 